\title{
Bacteroides cellulosilyticus sp. nov., a cellulolytic bacterium from the human gut microbial community
}

Correspondence

Annick Bernalier-Donadille

bernal@clermont.inra.fr

\author{
Céline Robert, ${ }^{1}$ Christophe Chassard, ${ }^{1}$ Paul A. Lawson ${ }^{2}$ \\ and Annick Bernalier-Donadille ${ }^{1}$ \\ ${ }^{1}$ Unité de Microbiologie, INRA, Centre de Recherches de Clermont Ferrand - Theix, \\ 63122 Saint Genès - Champanelle, France \\ ${ }^{2}$ Department of Botany and Microbiology, University of Oklahoma, Norman, OK 73019, USA
}

A strictly anaerobic cellulolytic bacterium, strain $\mathrm{CRE} 21^{\top}$, was isolated from a human faecal sample. Cells were Gram-negative non-motile rods that were about $1.7 \mu \mathrm{m}$ in length and $0.9 \mu \mathrm{m}$ in width. Strain CRE2 $1^{\top}$ degraded different types of cellulose and was able to grow on a variety of carbohydrates. Cellulose and sugars were mainly converted to acetate, propionate and succinate. The $\mathrm{G}+\mathrm{C}$ content of the DNA was $41.1 \mathrm{~mol} \%$. $16 \mathrm{~S}$ rRNA gene sequence analysis revealed that the isolate belonged to the genus Bacteroides with highest sequence similarity to the type strain of Bacteroides intestinalis (98\%). DNA-DNA hybridization results revealed that strain CRE $21^{\top}$ was distinct from $B$. intestinalis (40\% DNA-DNA relatedness). Strain CRE2 $1^{\top}$ also showed several characteristics distinct from $B$. intestinalis. In particular, it exhibited different capacity to degrade polysaccharides such as cellulose. On the basis of phylogenetic analysis and the morphological, physiological and biochemical data presented in this study, strain CRE21 ${ }^{\top}$ can be readily differentiated from recognized species of the genus Bacteroides. The name Bacteroides cellulosilyticus sp. nov. is proposed to accommodate this organism. The type strain is CRE $21^{\top}\left(=\right.$ DSM $14838^{\top}=$ CCUG $\left.44979^{\top}\right)$.
Most of the bacterial species making up the human gut microbiota are strict anaerobes, the predominant organisms being members of the genus Bacteroides (Harmsen et al., 2002). Until recently, however, only a few Bacteroides species isolated from the human gut had been described (Salyers, 1984), most belonging to one of the ten species of the Bacteroides fragilis group. Recent investigations of this Bacteroides population have improved our knowledge of its structure, through isolation and description of novel species such as Bacteroides plebeius, Bacteroides coprocola, Bacteroides helcogenes, Bacteroides intestinalis, Bacteroides finegoldii and Bacteroides dorei (Kitahara et al., 2005; Bakir et al., 2006a, b, c). As Bacteroides species are numerically important, they are assumed to play key roles in the degradation and fermentation of organic matter present in the colon (Salyers, 1995). Some Bacteroides species were

Abbreviations: CMCase, carboxymethylcellulase; CWS, cell-wall spinach. The GenBank/EMBL/DDBJ accession number for the $16 \mathrm{~S}$ rRNA gene sequence of strain CRE $21^{\top}$ is AJ583243.

An unrooted neighbour-joining tree based on 16S rRNA gene sequences showing the phylogenetic relationships between strain CRE $21^{\top}$ and some related members of the genus Bacteroides, a figure showing the kinetics of cellulose degradation by strain CRE $21^{\top}$ and a table detailing the end products of cellulose fermentation by strain CRE $21^{\top}$ are available as supplementary material with the online version of this paper. indeed shown to be able to obtain carbon and energy from hydrolysis of soluble or hydrated polysaccharides (Bétian et al., 1977; Salyers, 1995). In addition, degradation of maize bran, oat bran and wheat bran was evidenced in one strain of Bacteroides ovatus (Martin et al., 1998) while one Bacteroides sp. isolate, but which was not further identified, was reportedly able to use pure cellulose (Bétian et al., 1977). Although insoluble polysaccharides, mainly found in the plant cell wall (cereals, fruits, vegetables), constitute one of the main sources of carbohydrates that are extensively degraded by the human gut microbiota, the fibrolytic population involved in the breakdown of these substrates remains rather poorly explored. During the course of a study on the predominant cellulose-degrading community from the human colon, a Gram-negative bacterium that showed high $16 \mathrm{~S}$ rRNA gene sequence similarity to members of the genus Bacteroides was isolated from a faecal sample. The present study describes this new isolate, designated strain $\mathrm{CRE} 21^{\mathrm{T}}$, and further proposes that it represents a novel species of the genus Bacteroides.

Strain CRE $21^{\mathrm{T}}$ was isolated from faeces of a non-methaneexcreting healthy volunteer ( 50 years old, male) by using a strictly anaerobic technique (Hungate, 1969). All liquid and solid media were prepared, dispensed and inoculated under $100 \% \mathrm{O}_{2}$-free $\mathrm{CO}_{2}$ gas. Freshly voided faeces $(1 \mathrm{~g})$ were transferred into $10 \mathrm{ml}$ sterile anoxic mineral solution and 
serial 10 -fold dilutions down to $10^{-11}$ were then carried out in mineral solution. These faecal dilutions were inoculated $(0.3 \mathrm{ml})$ into liquid basal cellulolytic (BC) medium $(10 \mathrm{ml}$ per tube) (Robert \& Bernalier-Donadille, 2003) with cellwall spinach (CWS) fraction at a final concentration of $0.7 \%$ as the sole energy source. CWS residue was obtained as described by Mosoni et al. (1993). After 15 days incubation at $37^{\circ} \mathrm{C}$, the presence of cellulolytic organisms in faecal dilution cultures was estimated by measuring carboxymethylcellulase (CMCase) activity. Detection of CMCase activity was performed by using an agar plate assay as described by Forano et al. (1994).

Strain CRE $21^{\mathrm{T}}$ was isolated from the highest dilution faecal cultures showing CMCase activity $\left(10^{-8}\right)$. Isolation was carried out by using solid BC medium containing CWS as energy source and the roll-tube technique. After three to five successive subcultures on roll-tubes and broth BC medium, the isolate was examined for purity using phase-contrast microscopy, in CWS- and glucose- $\left(2 \mathrm{~g} \mathrm{l}^{-1}\right)$ grown cultures. The medium used for further routine cultivation of strain CRE $21^{\mathrm{T}}$ was BC medium while growth and nutrition studies of strain CRE21 $1^{\mathrm{T}}$ were carried out in semi-synthetic BC medium (Robert et al., 2001). Cell morphology and motility were studied in 18-h glucose-grown cultures using phasecontrast microscopy and electron microscopy after negative staining of the whole-cell fraction with $2 \%$ uranyl acetate. Gram staining was determined by using conventional methodology. Examination of cell morphology and cellwall structure was also made on ultrathin sections by using transmission electron microscopy (Philips 400) after staining with uranyl acetate and lead citrate (Bernalier et al., 1996). The presence of catalase and cytochrome oxidase was examined using standard methods. The optimal growth temperature of strain $\mathrm{CRE} 21^{\mathrm{T}}$ was determined in semisynthetic $\mathrm{BC}$ medium containing glucose $\left(2 \mathrm{~g} \mathrm{l}^{-1}\right)$ at $\mathrm{pH} 6.8$ over a temperature range of $25-45^{\circ} \mathrm{C}$ (at $1{ }^{\circ} \mathrm{C}$ intervals). The influence of $\mathrm{pH}$ on growth of CRE2 $1^{\mathrm{T}}$ was evaluated in semi-synthetic BC medium containing glucose $\left(2 \mathrm{~g} \mathrm{l}^{-1}\right)$ at $37^{\circ} \mathrm{C}$. The $\mathrm{pH}$ range studied was $5.5-7.5$ (at $0.1 \mathrm{pH}$ unit intervals, adjusted with varying concentrations of $\mathrm{NaHCO}_{3}$ in the medium).

Cells of strain CRE2 $1^{\mathrm{T}}$ were rods with rounded ends, with a mean length of $1.7 \mu \mathrm{m}$ and mean width of $0.9 \mu \mathrm{m}$. Cells occurred singly or in pairs. Cells stained Gram-negative and thin sections examined via transmission electron microscopy showed a Gram-negative cell-wall structure. Negatively stained cells revealed the absence of flagella. Viable cells could not be recovered from cultures held at $100{ }^{\circ} \mathrm{C}$ for $10 \mathrm{~min}$ and no spores were observed in cellulose- or in glucose-grown cultures incubated at $37^{\circ} \mathrm{C}$ for 30 days or more. Strain CRE2 $1^{\mathrm{T}}$ was strictly anaerobic and required an $\mathrm{O}_{2}$-free medium at a redox potential sufficient to decolorize resazurin $\left(E_{0}=-50 \mathrm{mV}\right)$. The cells did not possess catalase or cytochrome oxidase activity. With glucose as substrate, the optimal growth temperature was $37^{\circ} \mathrm{C}$ with growth occurring from 30 to $39^{\circ} \mathrm{C}$. Strain CRE $21^{\mathrm{T}}$ grew from an initial pH of 6.5 up to 7.2, with optimal growth at pH 6.8 . These optimal conditions of growth are in line with those found in the human colon. Rumen fluid was not required for growth.

DNA extraction, PCR and sequencing of the 16S rRNA gene of strain CRE2 $1^{\mathrm{T}}$ were performed as reported by Bernalier et al. (1996). Strain CRE $21^{\mathrm{T}}$ was grown for $24 \mathrm{~h}$ in $50 \mathrm{ml} \mathrm{BC}$ medium with glucose $\left(2 \mathrm{~g} \mathrm{l}^{-1}\right)$ as carbon source. Cells were harvested by centrifugation for $15 \mathrm{~min}$ at $9000 \mathrm{~g}$ at $4{ }^{\circ} \mathrm{C}$. The bacterial pellet was then subjected to DNA extraction (Easy DNA kit Genomic DNA Isolation; Invitrogen BV). The $16 \mathrm{~S}$ rRNA gene was then amplified using the universal primers F8 (5'-AGAGTTTGATCMTGGCTC-3') and 1492R (5'GNTACCTTGTTACGACTT-3'). Approximately $50 \mathrm{ng}$ of purified PCR product was included in a $20-\mu$ l sequencing reaction. Sequencing reactions were performed using a Dye Terminator Cycle Sequencing Ready Reaction kit (Perkin Elmer) according to the manufacturer's specifications. All reactions were carried out with an ABI Prism cycle sequencing kit and gels were run on an ABI PRISM 310 automated sequencer. The closest known relatives of the new isolate were determined by performing database searches by using the program FASTA (Pearson \& Lipman, 1985). These sequences and those of other related strains were retrieved from GenBank and aligned with the newly determined sequences according to the program SEQtools (http://www. seqtools.dk). The resulting multiple sequence alignment was corrected manually by using the program GeneDoc (Nicholas et al., 1997) and a phylogenetic tree was constructed according to the neighbour-joining method (Saitou \& Nei, 1987) with the programs SEQtools and TREEVIEW (Page, 1996). The $\mathrm{G}+\mathrm{C}$ content of the genomic DNA was determined by HPLC by the Deutshe Sammlung von Mikroorganismen und Zellkulturen GmbH (DSMZ, Braunschweig, Germany).

The 16S rRNA gene of strain CRE21 $1^{\mathrm{T}}$ was sequenced (1422 bases) and phylogenetic analysis revealed that this cellulolytic bacterium was most closely related to members of the phylum Bacteroidetes. Strain CRE2 $1^{\mathrm{T}}$ shared 97-98\% $16 \mathrm{~S}$ rRNA gene sequence similarity with its most closely related species, B. intestinalis, and only $92 \%$ with B. helcogenes. A phylogenetic tree showing the relationships of strain CRE2 $1^{\mathrm{T}}$ to other Bacteroides species is available as Supplementary Fig. S1 in IJSEM Online. The G $+\mathrm{C}$ content of the DNA of strain CRE $21^{\mathrm{T}}$ was $41.1 \mathrm{~mol} \%$; reported values for $B$. intestinalis and $B$. helcogenes are 44 and $45 \mathrm{~mol} \%$, respectively (Table 1 ).

Given that the 16S rRNA gene sequence similarity between strain CRE2 $1^{\mathrm{T}}$ and B. intestinalis was close to $98 \%$, DNADNA hybridization experiments between these two taxa were performed by the DSMZ service. DNA of strain CRE $21^{\mathrm{T}}$ and of $B$. intestinalis DSM $17393^{\mathrm{T}}$ was isolated by using a French pressure cell from cells harvested from brain heart infusion broth medium and was further purified by chromatography on hydroxyapatite (Cashion et al., 1977). DNA-DNA hybridization was carried out as described by 
Table 1. Differential characteristics between strain $\mathrm{CRE} 21^{\top}$ and related Bacteroides species

Taxa: 1, strain CRE21 ${ }^{\mathrm{T}}$; 2, B. intestinalis DSM $17393^{\mathrm{T}}$ (data from Bakir et al., 2006a); 3, B. helcogenes DSM $20613^{\mathrm{T}}$ (Kitahara et al., 2005; Bakir et al., 2006a). +, Positive; -, negative; W, weak.

\begin{tabular}{|c|c|c|c|}
\hline Characteristic & 1 & 2 & 3 \\
\hline Aesculin hydrolysis & $\mathrm{W}$ & + & + \\
\hline \multicolumn{4}{|l|}{ Acid produced from: } \\
\hline Salicin & $\mathrm{W}$ & + & + \\
\hline D-Cellobiose & $\mathrm{w}$ & + & + \\
\hline L-Arabinose & $\mathrm{W}$ & + & - \\
\hline Trehalose & - & - & - \\
\hline \multicolumn{4}{|l|}{ Enzymic reactions: } \\
\hline$\alpha$-Fucosidase & $\mathrm{W}$ & + & + \\
\hline 6-Phospho- $\beta$-galactosidase & - & - & + \\
\hline$\alpha$-Arabinosidase & + & + & - \\
\hline$\beta$-Glucuronidase & - & - & + \\
\hline Proline arylamidase & - & - & + \\
\hline Phenylalanine arylamidase & $\mathrm{w}$ & - & + \\
\hline Tyrosine arylamidase & W & - & - \\
\hline Major cellular fatty acids & $\begin{array}{l}\text { anteiso- } \mathrm{C}_{15: 0}, \mathrm{C}_{15: 0} \\
\quad \text { iso- } \mathrm{C}_{17: 0} 3-\mathrm{OH}\end{array}$ & $\begin{array}{c}\text { anteiso- } \mathrm{C}_{15: 0}, \\
\text { iso- } \mathrm{C}_{17: 0} 3-\mathrm{OH}, \mathrm{C}_{18: 1} \omega 7 c \\
\mathrm{C}_{16: 0} 3-\mathrm{OH}\end{array}$ & $\begin{array}{c}\text { anteiso- } \mathrm{C}_{15: 0}, \\
\text { iso- } \mathrm{C}_{17: 0} 3-\mathrm{OH}, \\
\mathrm{C}_{18: 1} \omega 7 c\end{array}$ \\
\hline DNA $G+C$ content $(\mathrm{mol} \%)$ & 41.1 & 44 & 45 \\
\hline
\end{tabular}

De Ley et al. (1970) and modified by Huß et al. (1983) by using a model Cary 100 Bio UV/VIS spectrophotometer equipped with a Peltier-thermostatted $6 \times 6$ multicell changer and a temperature controller with in situ temperature probe. Strain CRE $21^{\mathrm{T}}$ showed DNA-DNA relatedness of $40 \%$ with B. intestinalis DSM $17393^{\mathrm{T}}$. This low DNA-DNA relatedness value $(<70 \%)$ with its most closely related species indicated that strain $\mathrm{CRE} 21^{\mathrm{T}}$ represented a novel species.

Utilization of different substrates by strain CRE $21^{\mathrm{T}}$ was determined with semi-synthetic BC medium containing several carbon sources. Carbon sources were added from sterile stock solutions to a final concentration of $10 \mathrm{mM}$. Carbon source utilization by strain CRE $21^{\mathrm{T}}$ was determined after incubation of the cultures at $37^{\circ} \mathrm{C}$ for at least 4 days and by examination of the ability of the strain to maintain growth after three successive transfers on the same substrate. Bacterial growth was monitored by determining the optical density of the culture at $600 \mathrm{~nm}\left(\mathrm{OD}_{600}\right)$. Other biochemical and enzymic activity tests were performed by using the API Rapid ID 32AN and API ZYM test kit systems (bioMérieux) according to the manufacturer's instructions and anaerobic incubation at $37^{\circ} \mathrm{C}$. Furthermore, the cellular fatty acid profile of strain CRE $21^{\mathrm{T}}$ was determined using gas chromatography at the Culture Collection, University of Göteborg (Sweden). End products of cellulose and glucose fermentation were determined in 12-day and 24-h cultures, respectively. Gases in the headspace of cultures and shortchain fatty acids in culture supernatants were analysed by gas phase chromatography (Robert et al., 2001). Formate, succinate, ethanol and lactate production were measured using enzymic methods (Roche).
Strain CRE2 $1^{\mathrm{T}}$ was able to utilize a variety of substrates. Sugar utilization and enzymic activity patterns of strain CRE $21^{\mathrm{T}}$ were similar to those of $B$. intestinalis. However, strain CRE $21^{\mathrm{T}}$ could be differentiated from $B$. intestinalis and $B$. helcogenes based on several characteristics (Table 1). The major cellular fatty acid of strain CRE $21^{\mathrm{T}}$ was anteiso$\mathrm{C}_{15: 0}(37.8 \%)$ in agreement with data for the genus Bacteroides (Miyagawa et al., 1979) (Table 1). Other cellular fatty acids found in significant amounts in strain CRE2 $21^{\mathrm{T}}$ included iso- $\mathrm{C}_{17: 0} 3-\mathrm{OH}(12.7 \%)$ and $\mathrm{C}_{15: 0}(15 \%)$. The hydroxy acid iso- $\mathrm{C}_{17: 0} 3-\mathrm{OH}$ was also found in $B$. intestinalis and B. helcogenes but at a higher proportion of the total (19.2 and $17.7 \%$, respectively). The other cellular fatty acids found in B. intestinalis and B. helcogenes were different from those found in strain CRE $21^{\mathrm{T}}$ (Table 1). The end products of cellulose and glucose fermentation by strain CRE $21^{\mathrm{T}}$ were mainly acetate, propionate and succinate, with formate and lactate also being produced in smaller quantities (results are given in Supplementary Table S1 in IJSEM Online). Other Bacteroides species isolated from the human gut such as $B$. ovatus, Bacteroides thetaiotaomicron and B. fragilis similarly produced acetate, propionate and succinate from sugar fermentation (Salyers et al., 1981) but, in contrast to strain CRE $21^{\mathrm{T}}$, they did not produce lactate.

The ability of strain CRE $21^{\mathrm{T}}$ and of B. intestinalis DSM $17393^{\mathrm{T}}$ to degrade the main polysaccharides that make up dietary fibres was compared. Strain CRE $21^{\mathrm{T}}$ and $B$. intestinalis DSM $17393^{\mathrm{T}}$ were cultivated in liquid BC medium (10 ml per tube) containing Avicel pH 101 cellulose (100 mg), Sigmacell type 101 cellulose $(100 \mathrm{mg})$, oat spelts xylan $(100 \mathrm{mg})$, pectin from citrus $(20 \mathrm{mg})$, starch from 
potatoes (20 mg) or CWS (100 mg) as sole energy source. Cultures were incubated at $37^{\circ} \mathrm{C}$ for $2-4$ days and three culture tubes were inoculated for each substrate. After incubation, substrate utilization was estimated for the two strains by measuring bacterial growth $\left(\mathrm{OD}_{600}\right)$. In cellulose-, xylan- and CWS-grown cultures, substrate disappearance was measured (disappearance of dry matter) and CMCase and xylanase activities were detected by using an agar plate test (Forano et al., 1994). Cellulase activities of strain CRE $21^{\mathrm{T}}$ were further determined by using enzymic assays in which reducing sugars released from carboxymethylcellulose and Avicel pH 101 cellulose were measured colorimetrically with glucose as standard (Robert \& BernalierDonadille, 2003). Each enzymic assay was performed in triplicate.

Strain CRE21 $1^{\mathrm{T}}$ and B. intestinalis DSM $17393^{\mathrm{T}}$ showed different capacities to utilize dietary polysaccharides (Table 2). Strain CRE2 $1^{\mathrm{T}}$ was able to degrade different types of cellulose (results are shown in Supplementary Fig. S2 in IJSEM Online), including the CWS cellulose, and expressed CMCase $\left[54.0 \pm 0.2 \mu \mathrm{g}\right.$ glucose $\mathrm{min}^{-1}(\mathrm{mg}$ protein $\left.\left.{ }^{-1}\right)\right]$ and avicellase $\left[24.0 \pm 0.1 \mu \mathrm{g}\right.$ glucose $\min ^{-1}$ $\left(\mathrm{mg}\right.$ protein $\left.\left.{ }^{-1}\right)\right]$ activities in cellulose-grown cultures. $B$. intestinalis DSM $17393^{\mathrm{T}}$ was not able to grow on cellulosic substrates. Nevertheless, B. intestinalis showed the ability to degrade xylan whereas poor growth and weak xylanase activity were detected for strain $\mathrm{CRE} 21^{\mathrm{T}}$. The two bacterial taxa were able to use pectin and starch but $B$. intestinalis showed poor ability to degrade starch compared with strain CRE $21^{\mathrm{T}}$. Polysaccharide utilization profiles thus differentiated between strain CRE $21^{\mathrm{T}}$ and B. intestinalis DSM $17393^{\mathrm{T}}$. Strain CRE $21^{\mathrm{T}}$ remains the sole Bacteroides representative isolated from the human gut and described to date that is able to degrade cellulose.

On the basis of the phenotypic, genotypic and phylogenetic data presented here, we propose that strain CRE $21^{\mathrm{T}}$ represents a novel species of the genus Bacteroides. Strain CRE2 $1^{\mathrm{T}}$ showed properties that characterize it as typical for the genus Bacteroides: Gram-negative rods, non-spore-forming,

Table 2. Differential abilities of strain $\mathrm{CRE} 21^{\top}$ and $B$. intestinalis DSM $17393^{\top}$ to degrade various polysaccharides

+ , Positive; -, negative; w, weak. Both strains degraded pectin.

\begin{tabular}{|c|c|c|}
\hline $\begin{array}{l}\text { Polysaccharide } \\
\text { degradation }\end{array}$ & $\begin{array}{c}\text { Strain } \\
\text { CRE21 }^{\mathrm{T}}\end{array}$ & $\begin{array}{l}\text { B. intestinalis } \\
\text { DSM } 17393^{T}\end{array}$ \\
\hline Cellulose Avicel pH 101 & + & - \\
\hline Cellulose Sigmacell 101 & + & - \\
\hline Starch & + & $\mathrm{W}$ \\
\hline Xylan & $\mathrm{W}$ & + \\
\hline CWS & + & - \\
\hline
\end{tabular}

non-motile, obligately anaerobic with a $\mathrm{G}+\mathrm{C}$ content ranging from 40 to $48 \mathrm{~mol} \%$ (Shah, 1992), saccharolytic, producing acetate and succinate as the major metabolic end products (Holdeman \& Moore, 1974) and anteiso- $\mathrm{C}_{15: 0}$ as the major cellular fatty acid (Miyagawa et al., 1979). Strain CRE $21^{\mathrm{T}}$ was most closely related to $B$. intestinalis, which was isolated from the human colon, but these two taxa showed a low level of DNA-DNA relatedness $(<70 \%)$. In addition, phenotypic differences could be shown between strain CRE $21^{\mathrm{T}}$ and $B$. intestinalis, in particular in their abilities to degrade polysaccharides. Strain CRE $21^{\mathrm{T}}$ is characterized by its ability to degrade cellulose compared with $B$. intestinalis as well as other Bacteroides species described from the human gut. Given this physiological characteristic, we propose the name Bacteroides cellulosilyticus sp. nov. to accommodate strain CRE21 ${ }^{\mathrm{T}}$.

\section{Description of Bacteroides cellulosilyticus sp. nov.}

Bacteroides cellulosilyticus (cell.u'lo.si.ly'ti.cus. N.L. n. cellulosum cellulose; Gr. adj. lutikos loosening, dissolving; N.L. adj. lyticus - a -um dissolving; N.L. masc. adj. cellulosilyticus cellulose-dissolving).

Cells are non-motile rods, $1.7 \mu \mathrm{m}$ in lengh and $0.9 \mu \mathrm{m}$ in width. Gram-negative by staining and cell-wall ultrastructure. No heat-resistant endospores are formed. Strictly anaerobic. Colonies developed on glucose-BC agar medium are white to slightly brown, translucent, circular with entire margins and about $2-5 \mathrm{~mm}$ in diameter. Cytochrome oxidase- and catalase-negative. Metabolizes cellulose to acetate, propionate and succinate. Also ferments glucose, sucrose, fructose, maltose, xylose, galactose, ribose, melibiose, mannose, lactulose, galacturonic acids, pectin, starch and cellulose. Poor growth is exhibited with lactose, raffinose, arabinose, cellobiose, aesculin, xylan and salicin. No growth is observed on trehalose, mannitol, inositol, sorbitol or fucose. Positive reactions are obtained with the API Rapid ID 32AN and API ZYM systems for $N$-acetyl- $\beta$-glucosaminidase, alkaline phosphatase, alanine arylamidase, $\alpha$-arabinosidase, $\alpha$-galactosidase, $\beta$-galactosidase, $\alpha$-glucosidase, $\beta$ glucosidase, glutamic acid decarboxylase, glutamyl glutamic acid arylamidase, leucyl glycine arylamidase, mannose, raffinose, indole $\alpha$-fucosidase (weak), phenylalanine arylamidase (weak), tyrosine arylamidase (weak), acid phosphatase, naphthol-AS-BI-phosphohydrolase and esterase lipase C8 (weak). Growth occurs between 30 and $39^{\circ} \mathrm{C}$, and $\mathrm{pH} 6.5$ and 7.2. Optimal growth conditions are $37^{\circ} \mathrm{C}$ and $\mathrm{pH}$ 6.8. Rumen fluid is not required for growth. Major fatty acids are anteiso- $\mathrm{C}_{15: 0}(37.8 \%)$, iso- $\mathrm{C}_{17: 0} 3-\mathrm{OH}(12.7 \%)$ and $\mathrm{C}_{15: 0}(15 \%)$. The $\mathrm{G}+\mathrm{C}$ content of the DNA of the type strain is $41.1 \mathrm{~mol} \%$.

The type strain, CRE $21^{\mathrm{T}}\left(=\mathrm{DSM} 14838^{\mathrm{T}}=\mathrm{CCUG} 44979^{\mathrm{T}}\right)$, was isolated from human faeces of a non-methane-excreting individual. 


\section{Acknowledgements}

C.R. and C.C. were supported by fellowships from the French Ministère de la Recherche et de l'Enseignement Supérieur. We express our thanks to B. Lassalas for her help in GC analyses of fermentation end products.

\section{References}

Bakir, M. A., Kitahara, M., Sakamoto, M., Matsumoto, M. \& Benno, Y. (2006a). Bacteroides intestinalis sp. nov., isolated from human faeces. Int J Syst Evol Microbiol 56, 151-154.

Bakir, M. A., Kitahara, M., Sakamoto, M., Matsumoto, M. \& Benno, Y. (2006b). Bacteroides finegoldii sp. nov., isolated from human faeces. Int J Syst Evol Microbiol 56, 931-935.

Bakir, M. A., Sakamoto, M., Kitahara, M., Matsumoto, M. \& Benno, Y. (2006c). Bacteroides dorei sp. nov., isolated from human faeces. Int J Syst Evol Microbiol 56, 1639-1643.

Bernalier, A., Willems, A., Leclerc, M., Rochet, V. \& Collins, M. D. (1996). Ruminococcus hydrogenotrophicus sp. nov., a new $\mathrm{H}_{2} / \mathrm{CO}_{2}$ utilizing acetogenic bacterium isolated from human feces. Arch Microbiol 166, 176-183.

Bétian, H. G., Linehan, B. A., Bryant, M. P. \& Holderman, L. V. (1977). Isolation of cellulolytic Bacteroides sp. from human feces. Appl Environ Microbiol 33, 1009-1010.

Cashion, P., Hodler-Franklin, M. A., McCully, J. \& Franklin, M. (1977). A rapid method for base ratio determination of bacterial DNA. Anal Biochem 81, 461-466.

De Ley, J., Cattoir, H. \& Reynaerts, A. (1970). The quantitative measurement of DNA hybridization from renaturation rates. Eur $J$ Biochem 12, 133-142.

Forano, E., Brousolle, V., Gaudet, G. \& Bryant, J. A. (1994). Molecular cloning, expression and characterization of a new endoglucanase gene from Fibrobacter succinogenes S85. Curr Microbiol 28, 7-14.

Harmsen, H. M. J., Raangs, G. C., Degener, J. E. \& Welling, G. W. (2002). Extensive set of $16 \mathrm{~S}$ rRNA-based probes for detection of bacteria in human feces. Appl Environ Microbiol 68, 2982-2990.

Holdeman, L. V. \& Moore, W. E. C. (1974). Gram-negative anaerobic bacteria. In Bergey's Manual of Determinative Bacteriology, 8th edn, pp. 384-385. Edited by R. E. Buchanan \& N. E. Gibbons. Baltimore: Williams \& Wilkins.

Hungate, R. E. (1969). A roll tube method for the cultivation of strict anaerobes. Methods Microbiol 3B, 117-132.
Huß, V. A. R., Festl, H. \& Schleifer, K. H. (1983). Studies on the spectrophotometric determination of DNA hybridization from renaturation rates. Syst Appl Microbiol 4, 184-192.

Kitahara, M., Sakamoto, M., Ike, M., Sakata, S. \& Benno, Y. (2005). Bacteroides plebeius sp. nov. and Bacteroides coprocola sp. nov. isolated from human faeces. Int J Syst Evol Microbiol 55, 2143-2147.

Martin, S. A., Morrison, W. H. \& Akin, D. E. (1998). Fermentation of maize bran, oat bran and wheat bran by Bacteroides ovatus V975. Curr Microbiol 36, 90-95.

Miyagawa, E., Azuma, R. \& Suto, T. (1979). Cellular fatty acid composition in Gram-negative obligately anaerobic rods. J Gen Appl Microbiol 25, 41-51.

Mosoni, P., Besle, J. M., Cornu, A., Duran, H. \& Jouany, J. P. (1993). Wheat lignin labelling using $\left[\mathrm{U}_{-}{ }^{14} \mathrm{C}\right]$ phenylalanine or $\left[\mathrm{O}_{-}{ }^{14} \mathrm{CH}_{3}\right]$ sinapic acid for fermentation studies. J Agric Food Chem 41, 1349-1354.

Nicholas, K. B., Nicholas, H. B., Jr \& Deerfield, D. W., II (1997) GeneDoc: analysis and visualization of genetic variation. EMBnet News 4(2), 1-4. http://www.embnet.org/download/embnetnews/ embnet_news_4_2.pdf

Page, R. D. M. (1996). TreeView: an application to display phylogenetic trees on personal computers. Comput Appl Biosci 12, 357-358.

Pearson, W. R. \& Lipman, D. J. (1985). Rapid and sensitive protein similarity searches. Science 227, 1435-1441.

Robert, C. \& Bernalier-Donadille, A. (2003). The cellulolytic microflora of the human colon: evidence of microcrystalline cellulose-degrading bacteria in methane-excreting subjects. FEMS Microbiol Ecol 46, 81-89.

Robert, C., Del'Homme, C. \& Bernalier-Donadille, A. (2001). Interspecies $\mathrm{H}_{2}$ transfer in cellulose degradation between fibrolytic bacteria and $\mathrm{H}_{2}$-utilizing microorganisms from the human colon. FEMS Microbiol Lett 205, 209-214.

Saitou, N. \& Nei, M. (1987). The neighbor-joining method: a new method for reconstructing phylogenetic trees. Mol Biol Evol 4, 406425 .

Salyers, A. A. (1984). Bacteroides of the human lower digestive tract. Annu Rev Microbiol 38, 293-313.

Salyers, A. A. (1995). Fermentation of polysaccharides by human colonic anaerobes. In Dietary Fibre, pp. 29-35. Edited by C. Cherbut, J. L. Barry, D. Lairon \& M. Durand. Paris: John Libbey Eurotext.

Salyers, A. A., Gherardini, F. \& O'Brien, M. (1981). Utilization of xylan by two species of human colonic Bacteroides. Appl Environ Microbiol 41, 1065-1068.

Shah, H. N. (1992). The genus Bacteroides and related taxa. In The Prokaryotes, 2nd edn, pp. 3593-3605. Edited by A. Balows, H. G. Trüper, M. Dworkin, W. Harder \& K.-H. Scheifer. New York: Springer. 